\title{
Video-based e-learning tools for geriatric nursing education
}

\author{
Vera Habes*1, Alice Bakker ${ }^{2}$, Thijs Aarts ${ }^{3}$, Bianca Buurman ${ }^{4}$ \\ ${ }^{1}$ Faculty of Health Care, University of Applied Sciences Utrecht, Utrecht, the Netherlands \\ ${ }^{2}$ Faculty of Nursing, Vocational Education College Flevoland, Almere, the Netherlands \\ ${ }^{3}$ LEO Learning, Brighton, United Kingdom \\ ${ }^{4}$ Department of Internal Medicine, Section of Geriatric Medicine, Academic Medical Center, Amsterdam, the Netherlands
}

Received: September 26, 2021

DOI: $10.5430 /$ jnep.v12n4p59
Accepted: November 26, $2021 \quad$ Online Published: December 14, 2021

URL: https://doi.org/10.5430/jnep.v12n4p59

\begin{abstract}
Background: Future clinical challenges in nursing care of geriatric patients require educational courses that provide a high level of clinical reasoning skills. Serious Soap (www . serioussoap.nl/eng) is a video-based educational tool that combines entertainment with learning and reflection; it can serve as an attractive e-learning tool for nurses, nursing students, and tutors in geriatric care.

Objective: This article describes Serious Soap's development process, the lessons learned, and the most beneficial factors for student-centredness and teacher-centredness.

Conclusions: The lessons learned from the development process highlight that it is important to use the experiences from previous gamification projects, co-create with target users, conduct elaborate testing and research before launching the final version, and ensure sustainability. The most valuable features for student-centeredness were the use of humor, authentic critical situations, popular actors, and interactivity. The most favorable aspects for teacher-centeredness were free accessibility of the tool, evidence-based content, and the possibility of using different features of the tool in various manners.
\end{abstract}

Key Words: E-learning, Serious game, Geriatric nursing education, Development process

\section{INTRODUCTION}

In the past decade, evidence-based knowledge in the nursing field has increased and become available due to the further development of nursing science and open access to scientific databases. ${ }^{[1]}$ The available evidence, however, is insufficiently applied in geriatric daily practice. ${ }^{[2,3]}$ Educational tools that are attractive to nursing students and professionals in geriatrics may facilitate the application of scientific knowledge in daily practice. ${ }^{[4,5]}$

E-learning materials are appealing to health care professionals and students in various health care disciplines such as dentistry, ${ }^{[6]}$ ergonomics, ${ }^{[7]}$ rehabilitation science, ${ }^{[8]}$ medicine ${ }^{[9,10]}$ and nursing. ${ }^{[1-14]}$ E-learning materials for health care professionals are proven to be at least as effective as conventional learning, ${ }^{[15]}$ and several studies demonstrate that they are more effective for improving knowledge, skills, and satisfaction. ${ }^{[16-18]}$ During the coronavirus disease 2019 (COVID-19) pandemic, the need for e-learning materials has increased, and the trend is expected to continue. ${ }^{[?][19,20]}$

E-learning materials take many forms, such as multimedia learning modules using quizzes and media, enhanced serious games that include an avatar and computer animation, virtual

\footnotetext{
*Correspondence: Vera Habes; Email: vera.habes@ @u.nl; Address: Faculty of Health Care, University of Applied Sciences Utrecht, Utrecht, the Netherlands.
}

Published by Sciedu Press 
reality simulations, and interactive videos. Interactive video tools integrate narrative videos in combination with quizzes, feedback, and educational interventions. Interactive video's may be gamified for users by implementing game mechanics such as a scoring element and rating. ${ }^{[21,22]}$ Interactive videos provide the opportunity to practice clinical reasoning skills. They enhance learning through the process of allowing users to experience failure and reflection. ${ }^{[22-24]}$ In addition, the interactive elements support involvement with the subject by combining learning and entertainment. ${ }^{[25,26]}$

In the Netherlands, two former projects have been developed regarding clinical reasoning in geriatric care, that involved interactive videos: Vangnet and Malaika. Vangnet was created specifically for postgraduate education in geriatric care, focusing on fall risk prevention and dementia detection. Three Dutch nursing homes implemented the tool, which combined elements of soap operas and serious gaming. A significant improvement was observed regarding fall risk prevention, and nurses perceived it as an attractive e-learning tool. ${ }^{[27]}$ Malaika is a soap opera about nursing students' experiences during their internships in geriatric care, and it was broadcast on Dutch national television in 2012 using influencers. This soap opera had a positive influence on interest in geriatric care. $^{[28]}$

Despite the positive experiences regarding Vangnet and Malaika, researchers have not explored their effects on knowledge of geriatrics. Therefore, the Amsterdam University Medical Center initiated in 2015 the development of Serious Soap and co-created it with four nursing education institutes (three vocational and one bachelor level), the National Dutch Employers Association of Elderly Care (ACTIZ), one homecare centre (Care Group Almere), and one elderly association (Circle Elderly Care and Partners). The main goal was to develop an attractive e-learning tool concerning geriatric nursing care and to explore its educational benefits.

Research on video-based learning tools for nurses describes the development process mostly as a summarized part of the observational or experimental findings. ${ }^{[29,30]}$ Studies that more thoroughly describe the development process are mainly focused on the acute nursing care settings such as stroke care, cardiac care, and pulmonary care scenarios. ${ }^{[31,32]}$ Research on the development process of video-based learning tools for chronic geriatric nursing care is limited. To address this gap, the developers of Serious Soap assessed, five years after the development, the development process and lessons learned.

This article aims to a) describe the development process of Serious Soap —a Dutch interactive, video-based e-learning tool 60 for geriatric nursing care-as well as the lessons learned and b) explore the most beneficial factors for student-centredness and teacher-centredness. An English-translated version of the tool is freely accessible at serioussoap.nl/eng.

\section{Ethics}

The Dutch Ethical Board for Medical Education (NVMO) approved the study (NVRB number 594). All participants provided informed consent. The advisory board received a $€ 100,000$ subsidization from ZonMw, the National Care for the Elderly Programme, grant number 301200011.

\section{RESULTS}

During the development, we identified five phases, based on the Medical Research Framework, ${ }^{[33]}$ preparation, development, testing, implementation-dissemination, and evaluation (see Table 1).

\subsection{Preparation phase}

We started by forming three teams for different roles: the advisory board, the peer feedback group, and the development team. The advisory board, comprised representatives of the above-described stakeholders, and identified the target users: nursing students at vocational nursing schools and professional nurses in homecare. In addition, they chose three main subjects that have evidence-based value for the nursing profession in geriatrics: 1) comprehensive geriatric assessment (CGA), 2) pain management, and 3) self-management. The advisory board was further responsible for monitoring the development process and the finances. The second team was a peer feedback group, comprising nine vocational and three bachelor nursing students, two homecare nurses, eight professors, and two scientists. The peer feedback group delivered feedback to maximally connect the content to the preferences of the target users. The third team was the development team, comprising a lecturer at a regional vocational education centre, Flevoland (ROC Flevoland); a lecturer at the University of Applied Sciences, Utrecht; a professor at the Amsterdam University Medical Center; and an IT developer. The development team explored educational gamification tools regarding nursing health care and sampled the opinion of the target audience regarding the attractiveness of these tools. They formulated success criteria, such as the use of humour, real-life characters, professional acting, and accessibility of the tool. The development team conducted a literature study on the key subjects and formulated additional learning outcomes on the basis of Bloom's revised taxonomy. Bloom's taxonomy is a model that classifies the targets of the learning process; the six categories are reproduce, understand, apply, analyse, evaluate, and create. ${ }^{[34]}$ The development team defined learning outcomes in the context of three categories: reproduce, understand, and apply.

ISSN 1925-4040 E-ISSN 1925-4059 
Table 1. Phases of development

\begin{tabular}{|c|c|}
\hline Phases of development & \\
\hline $\begin{array}{l}\text { Preparation } \\
3 \text { months }\end{array}$ & $\begin{array}{l}\text { Forming advisory board, feedback peer group, and development team } \\
\text { Choosing target audience } \\
\text { Choosing key subjects } \\
\text { Exploring gamification tools in health care } \\
\text { Formulating success criteria for pilot project: Vangnet and Malaika } \\
\text { Studying literature on key subjects } \\
\text { Formulating learning outcomes }\end{array}$ \\
\hline $\begin{array}{l}\text { Development } \\
\text { content and gamification } \\
6 \text { months }\end{array}$ & $\begin{array}{l}\text { Formulating critical scenarios } \\
\text { Formulating questions } \\
\text { Holding Round } 1 \text { feedback with peer group } \\
\text { Choosing Information Technology tool } \\
\text { Creating video and developing a making-of } \\
\text { Integrating content with game elements } \\
\text { Holding Round } 2 \text { feedback with peer group } \\
\text { Creating PowerPoints, a library, and tutor training }\end{array}$ \\
\hline $\begin{array}{l}\text { Testing } \\
3 \text { months }\end{array}$ & $\begin{array}{l}\text { Launching version } 1.0 \\
\text { Conducting a pre- and post-test quantitative study } \\
\text { Conducting a qualitative study }\end{array}$ \\
\hline $\begin{array}{l}\text { Implementation-dissemination } \\
9 \text { months }\end{array}$ & $\begin{array}{l}\text { Transforming } 1.0 \text { into } 2.0 \text { based on testing phase } \\
\text { Launching version } 2.0 \\
\text { Developing a trailer } \\
\text { Publishing links to Dutch platforms } \\
\text { Publishing article in national journal } \\
\text { Developing English version }\end{array}$ \\
\hline $\begin{array}{l}\text { Evaluation } \\
3 \text { months }\end{array}$ & $\begin{array}{l}\text { Writing evaluation report } \\
\text { Publishing research in international journal }\end{array}$ \\
\hline
\end{tabular}

\subsection{Development phase: content}

The next step was describing critical scenarios regarding the three key subjects: CGA, pain management, and selfmanagement. Narrative elements were added to a storyline based on real-life characters. The script contained not only critical situations but also a couple of humorous scenes regarding geriatric challenges for two frail geriatric clients and two nurses. The scenarios were situated in homecare as well as in the hospital setting. Then, the development team formulated questions and a feedback loop to confront players with the consequences of their choices. Incorrect answers resulted in a gradual decline in the clients' physical and mental health, and correct answers kept the clients in optimal condition.

The peer feedback group provided advice about the actors who should be approached for the videos. They provided feedback twice on the real-life value of the critical scenarios and the relevance of the questions.

A film crew was formed, and two young Dutch celebrities were engaged. The videos were shot in the practical clinics of the University of Applied Sciences, Utrecht (see Figure 1), and in two private homes. Additional educational material was developed, such as PowerPoint presentations, tutorials, and a digital library.

\subsection{Development phase: gamification}

The IT developer used the pilot project Vangnet, created in 2010, to test the design approach of Serious Soap. Vangnet offered a similar user experience as Serious Soap does, with a few more game mechanics. However, during playtesting with the target audience, the competitive game elements seemed to deter health professionals rather than attract them. The IT developer tweaked the concept and simplified some of these elements to focus more on the learning content and rich media. He used a model inspired by Roger Caillois' model ${ }^{[35]}$ to find a balance among several game mechanics. Caillois describes how balance among competition, chance, roleplay, thrill, and challenge can help users achieve a sense of play, which is ultimately what designers want to achieve when creating a game. The goal is not to abide by certain rules that will ensure the product is a game but instead guarantee that the product creates a sense of play while ensuring a perfect balance between learning and fun. The implementation of game mechanics, such as a scoring element and rating, created a sense of play, which made the overall user experience more fun and rewarding throughout. Articulate Story- 
line 360, an industry standard when it comes to e-learning https://articulate.com/), was used. development (Articulate Storyline 360, [New York, USA];

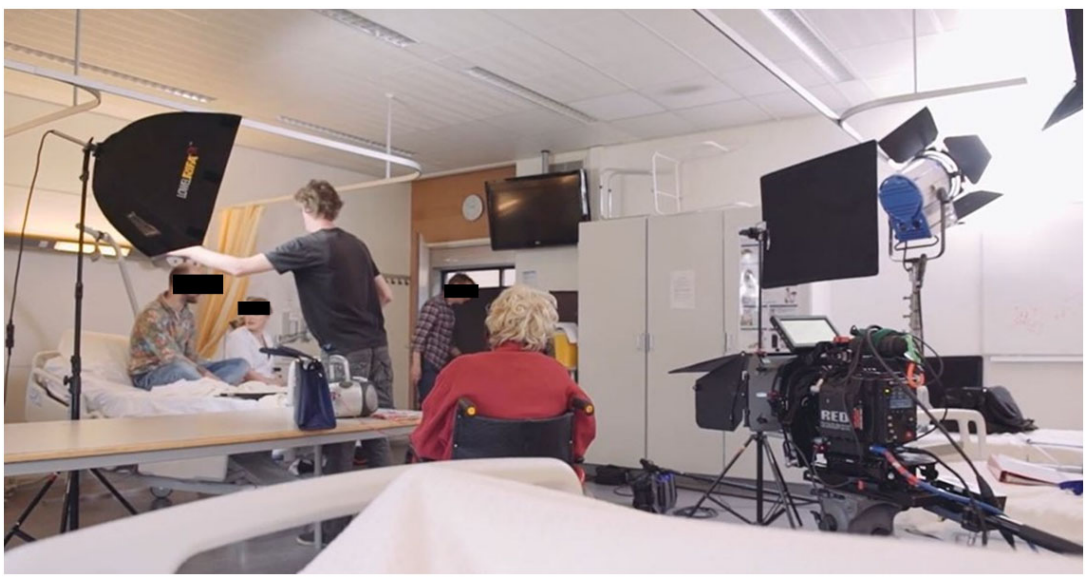

Figure 1. Practical Clinic of the University of Applied Sciences, Utrecht, for recording the videos in the hospital setting

\subsection{Testing phase}

Version 1.0 was tested extensively, as the level of interaction, structure, and scale pushed the storyline's boundaries. The technical testing was more time consuming than expected.

To investigate the usability of Serious Soap and its effects on the geriatric knowledge of nursing students and homecare nurses, a study was conducted with a mixed study design. We used a pretest-posttest design to evaluate the learning outcomes in terms of geriatric knowledge and a qualitative approach to assess the usability of the tool. A total of 240 participants were included. A validated instrument, the Knowledge of Older People Quiz (KOP-Q) ${ }^{[36]}$ was used to evaluate geriatric knowledge. The qualitative study included observations of students while they played Serious Soap, semistructured focus groups, and individual interviews. The study demonstrated a significant increase in geriatric knowledge of $7.8 \%$ ( \pm 2.3 points on the KOP-Q; $95 \%$ confidence interval $1.4-3.2 ; p<.001)$. The qualitative data showed that Serious Soap contributed to reflective learning skills and was perceived as an attractive alternative to traditional learning due to its humorous and interactive elements. ${ }^{[37]}$ The flaws concerned technical deficits, such as slow performance and vagueness of the rating system. Version 2.0 was developed based on the recommendations of the qualitative study. The original three modules were changed to nine shorter modules to improve technical performance and speed. In addition, the rating system was adapted such that users could monitor their progress continuously.

\subsection{Implementation-dissemination phase}

Version 2.0 was implemented in the educational curriculum of the three vocational schools that participated in the study; two bachelor schools of nursing integrated the game into their first-year curricula. A trailer was published ${ }^{[38]}$ on several Dutch platforms concerning the elderly. Moreover, ACTIZ published a behind-the-scenes documentary, ${ }^{[39]}$ and a Dutch educational nursing journal published an article regarding the development process. ${ }^{[40]}$ In 2016, the Action Learning Network proclaimed Serious Soap to be a leading tool. ${ }^{[41]}$ Finally, Serious Soap was translated into English for broader dissemination. Teachers in the Netherlands unexpectedly appeared to use the tool in various ways. They regularly used the evidence-based content of the library as a reference and downloaded separate elements of the tool (videos, quizzes, PowerPoints) and integrated them into their educational needs of the moment. They even re-utilized videos for other e-learning materials in related nursing subjects.

\subsection{Evaluation phase}

An evaluation report was written based on the process and the research. The yearly average use of Serious Soap is between 4,000 and 5,000 unique visitors a year (see Figure 2). Five years after development, the total number of visitors is approximately 23,000 . The results of the research were published in Nurse Education Today.

\section{LESSONS LEARNED}

\subsection{Development process}

An important lesson learned from the preparation phase was the significance of using the experiences of former projects described in the literature and conducting a pilot project. The information helped us establish criteria to find a balance between attractiveness and usefulness and prevented us from developing useless gamification elements. An important lesson from the testing phase concerned the estimation of the 
technical testing period, which was considerably longer than we had expected. Moreover, it demonstrated the usability flaws that we could eliminate before launching the final version (version 2.0). A further lesson we learned from the implementation phase was that co-operation with several nursing schools in early stages facilitated the implementation process, as educators were already acquainted with the tool. A lesson from the dissemination phase was that rapid development of new evidence and information technology has forced us to keep updating the tool. As the tool Articulate Storyline Version 1 is no longer compatible with current mobile information technology, an updated mobile-friendly version 3.0 was released in 2019 (see Figure 3). This lesson taught us that we failed to add a final phase to our framework - covering sustainability - to guarantee updates of the evidence-based content and IT technology for future use.

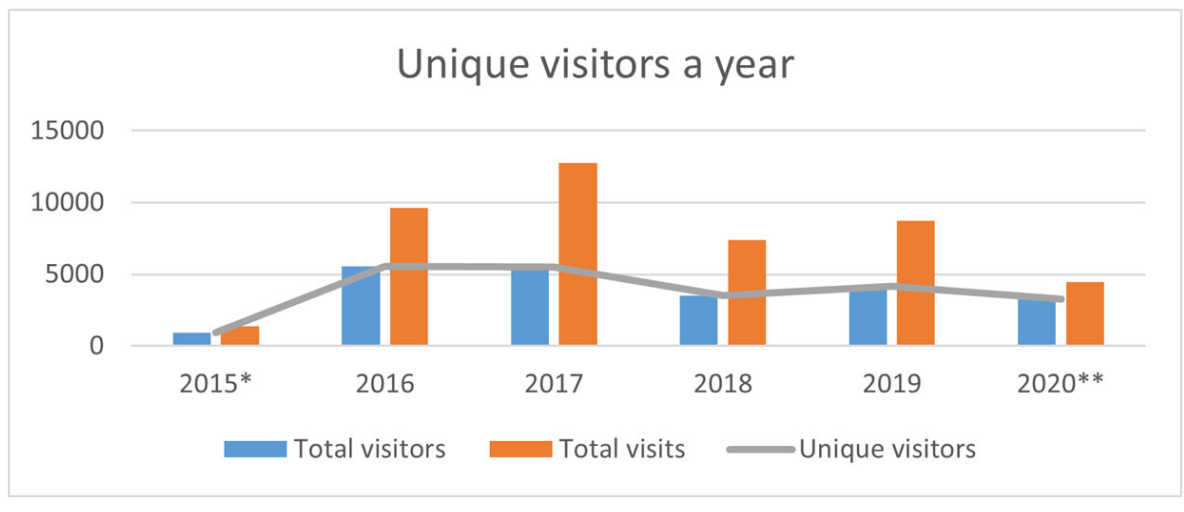

Figure 2. Unique visitors a year

*The game launched at the end of 2015.**The 2020 numbers are from January to October.

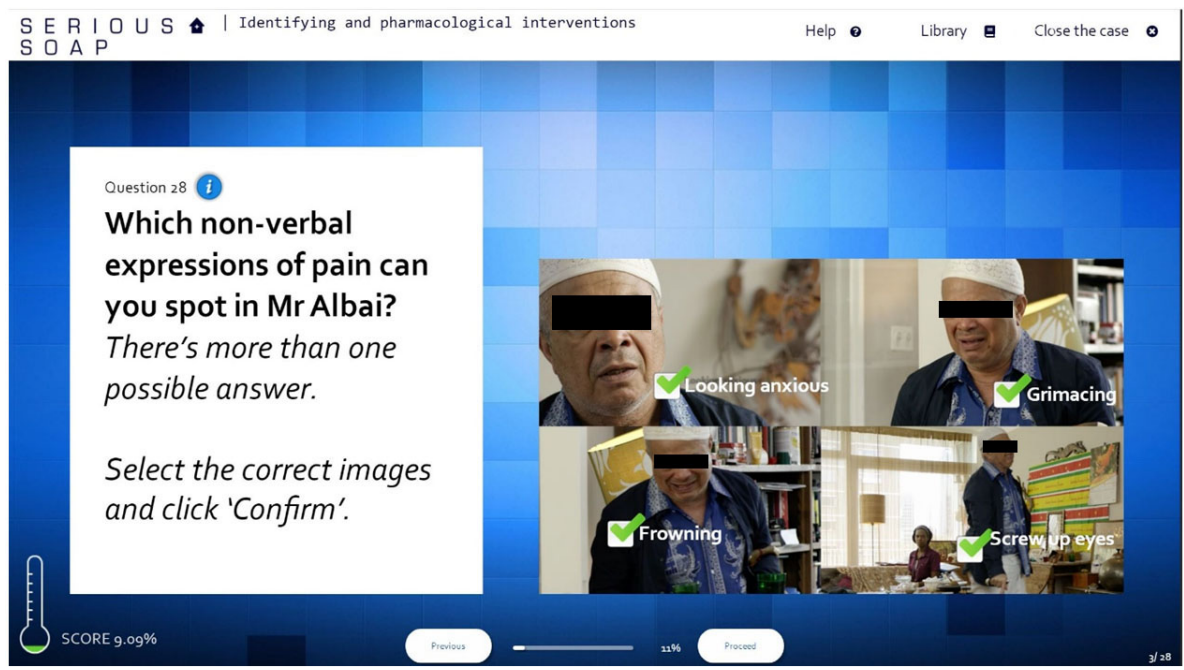

Figure 3. Screenshot Serious Soap 3.0

\subsection{Student-centredness}

The development phase taught us that peer feedback from the target audience is extremely valuable. The peer feedback group facilitated the creation of authentic critical situations, the use of humour, and the choice of Dutch celebrities-elements that enhanced the student-centred attractiveness. Furthermore, the elaborate results of the mixed study design during the testing phase supported our hypothesis that Serious Soap is perceived as an attractive tool because of the humoristic, interactive elements, that it has significant Published by Sciedu Press educational benefits for students, and that it contributes to their reflective learning skills.

\subsection{Teacher-centredness}

Regarding the dissemination phase, the development of a trailer and free accessibility of the tool were important success factors that enabled dissemination among teachers in the educational nursing field. Furthermore, the evidencebased content and the various ways in which teachers can use the separate elements of the tool seemed to be an essen- 
tial success factor that serves teachers' specific educational needs.

\section{Discussion}

We aimed to describe the development process of Serious soap and the lessons learned, as well as to explore the most beneficial factors for student- and teacher-centredness. The lessons learned relate to the significance of using experiences from former gamification projects, co-creation with the target users, elaborate testing and research before launching the final version, and care for sustainability. The most beneficial factors for student-centredness were the use of humour and popular actors, authentic critical situations, and interactivity. The most beneficial factors for teacher-centredness were free accessibility of the tool, evidence-based content, and the possibility to use different elements of the tool in various ways.

\subsection{Development process}

The lessons learned regarding the development process, such as the use of former gamification experiences, co-creation with target users, and elaborate testing and research, are confirmed by several studies on education learning innovations and action research, emphasizing the use of evidence and stakeholders during innovative processes. ${ }^{[42-44]}$ However, we had not foreseen the lack of a final phase, namely, sustainability. Although we had included a financial buffer for five years after implementation, we underestimated the importance of thinking ahead in the long term.

\subsection{Student-centredness}

The importance of humour and interactivity as beneficial factors for student-centredness are supported by several empirical studies. ${ }^{[45-49]}$ Humour and interactivity can be perceived as attractive elements that can increase attention and reinforce what is being taught. The finding on the relevance of authentic critical situations for student-centredness is endorsed by a study on computer-based simulations in the nursing field. ${ }^{[50]}$ This study revealed that authentic patientrelated experiences, including feedback and reflection tools, are important factors for clinical reasoning in nursing. These factors were taken into consideration during development. However, we used two-dimensional videos, whereas $360^{\circ}$ video techniques might have delivered more authentic interactive videos with a stronger appeal to the new generation of nurses. ${ }^{[51,52]}$ Furthermore, we used a decision tree based on a sequence of several questions. Every sequence resulted in only two possible endings: a happy ending or an unhappy ending. In this way, the user could not discern which critical situation was most crucial for the final ending. A decision tree with more differentiated opportunities could have led to more in-depth debriefing and reflection. ${ }^{[53]}$

\subsection{Teacher-centredness}

Serious Soap is an example of a blended learning tool due to its combination of web-based learning and face-to-face learning. ${ }^{[54]}$ The flexibility of the tool, the free access, and its English translation make it easily accessible, as proven by the number of users and the various methods of incorporation into several curricula of nursing education institutions. The tool may be perceived as a high-impact learning tool, according to the definition by Dochy. ${ }^{[55]}$ This theory describes several elements that enhance learning, such as feelings of urgency, learning agency, a combination of formal and informal learning, interactivity, hybrid learning, and assessment as learning. Serious Soap incorporates nearly all of these elements in the storytelling videos: the integration of video, pop-up questions, a library, and the freely accessible platform. This combination makes the tool highly beneficial for teachers.

A challenge regarding teacher-centredness is the demonstration of incorrect and non-evidence-based nursing actions in the videos to enhance dramatic involvement. Some researchers have argued against this approach for didactic reasons ${ }^{[56]}$ but others have not. ${ }^{[57]}$ Muller ${ }^{[58]}$ has recommended the use of misconceptions as a didactic principle in multimedia educational material, which convinced us to use the conflicts in the videos and to confute them with clear and timely feedback.

\section{Conclusion}

The aim of this article was first to describe Serious Soap's development process and the lessons learned and then to explore the most beneficial factors for student- and teachercentredness. Based on the lessons learned, the following actions are key: 1) using experiences from former gamification projects, 2) co-creating with the target users, 3) conducting elaborate testing and research before launching the final version, and 4) caring for sustainability. In addition, the most beneficial factors for student-centredness were 5) the use of humour, authentic critical situations, popular actors, and interactivity, while the most beneficial factors for teacher-centredness were 6) free accessibility of the tool, 7) evidence-based content, and 8) the possibility to use different elements of the tool in various ways. These lessons can serve as recommendations for the future development of similar e-learning tools for nursing care.

\section{FUNDING}

The advisory board received a $€ 100,000$ subsidization from ZonMw, the National Care for the Elderly Programme, grant 
number 301200011

\section{ACKNOWLEDGements}

The authors thank representatives of the Academic Medical Center Amsterdam, Hogeschool Utrecht, Vocational Education College Midden Nederland, Flevoland and Amersfoort,
Care group Almere, National Dutch Employers Association of Elderly Care (ACTIZ) and the Circle Older Adults Care and Partners for the co-creation of Serioussoap.

\section{CONFLicts OF InTEREST Disclosure}

\section{REFERENCES}

[1] Hoegen P, Verhoef J, Munten G, et al. Evidence based practice voor verpleegkundigen. Gezamenlijke, geïnformeerde besluitvorming. Amsterdam. 2020.

[2] Dikken J, Bakker A, Hoogerduijn JG, et al. Comparisons of knowledge of Dutch nursing students and hospital nurses on aging. The Journal of Continuing Education in Nursing. 2018; 49(2): 84-90. PMid:29381172 https : //doi .org/10.3928/00220124-20180 116-08

[3] Hamers JPH. De intramurale ouderenzorg: Nieuwe leiders, nieuwe kennis, nieuwe kansen. 2011. Available from: https://www.raadrvs.nl/binaries/raadrvs/documenten /publicaties/2012/06/08/achtergrondstudie-toekoms tintramurale-ouderenzorg/Achtergrondstudie_Toekoms tIntramurale_Ouderenzorg.pdf

[4] Snoeren MWC. Working = Learning. A complexity approach to workplace learning within residential care for older people. (Master thesis, Vrije Universiteit Amsterdam). 2015. Available from: http://dare.ubvu.vu.nl/bitstream/handle/1871/ $53048 /$ end? sequence $=13$

[5] Strijbos MJ. Gerontology and geriatrics in Dutch educational programmes (Master thesis, Utrecht University). 2011. Available from: https://dspace.library.uu.nl/bitstream/handle/ 1874/211097/Research+rapport+definitief+Marije+Str ijbos. pdf? sequence $=1$

[6] Wu JH, Du JK, Lee CY. Development and questionnaire-based evaluation of virtual dental clinic: a serious game for training dental students. Medical Education Online. 2021; 26(1): 1983927. PMid:34694980 https://doi.org/10.1080/10872981.2021. 1983927

[7] Kanafi I. Increasing Students Awareness of Safety Designing Workplace Base on Ergonomic Principle Using Video. Universal Journal of Educational Research. 2020; 8(12): 6902-6907. https: //doi.org/10.13189/ujer.2020.081256

[8] Proença JP, Quaresma C, Vieira P. Serious games for upper limb rehabilitation: a systematic review. Disability and Rehabilitation: Assistive Technology. 2018; 13(1): 95-100. PMid:28359181 https: //doi.org/10.1080/17483107.2017.1290702

[9] Gorbanev I, Agudelo-Londoño S, González RA, et al. A systematic review of serious games in medical education: quality of evidence and pedagogical strategy. Medical Education Online. 2018; 23(1) 1438718. PMid:29457760 https://doi.org/10.1080/108729 81.2018 .1438718

[10] Ruiz JG, Mintzer MJ, Leipzig RM. The impact of e-learning in medical education. Academic medicine. 2006; 81(3): 207-212 PMid:16501260 https://doi .org/10.1097/00001888-20060 3000-00002

[11] Buijs-Spanjers K. Improving delirium education: the role of experiential learning in a serious game (Doctoral dissertation). 2020. https://doi.org/10.33612/diss.126540538
[12] Johnsen HM, Fossum M, Vivekananda-Schmidt P, et al. Nursing students' perceptions of a video-based serious game's educational value: A pilot study. Nurse Education Today. 2018; 62: 62-68. PMid:29306100 https://doi.org/10.1016/j .nedt.2017.12 .022

[13] Blazeck AM, Katrancha E, Drahnak D, et al. Using interactive videobased teaching to improve nursing students' ability to provide patientcentered discharge teaching. Journal of Nursing Education. 2016; 55(5): 296-299. PMid:27115459 https://doi .org/10.3928/01 484834-20160414-11

[14] Odessa JPD, Raby T, Ravaut F, et al. Developing the Serious Games potential in nursing education. Nurse Education Today. 2013; 33(12): 1569-1575. PMid:23332500 https://doi.org/10.1016/j.ne dt. 2012.12.014

[15] Vaona A, Banzi R, Kwag KH, et al. E-learning for health professionals. Cochrane Database of Systematic Reviews. 2018 PMid:29355907 https://doi.org/10.1002/14651858.CD011 736. pub2

[16] Fontaine G, Cossette S, Maheu-Cadotte MA, et al. Efficacy of adaptive e-learning for health professionals and students: a systematic review and meta-analysis. BMJ Open. 2019; 9(8): e025252. PMid:31467045 https://doi.org/10.1136/bmjopen-2018-0 25252

[17] Gentry SV, Gauthier A, Ehrstrom BLE, et al. Serious gaming and gamification education in health professions: systematic review. Journal of Medical Internet Research. 2019; 21(3): e12994. PMid:30920375 https ://doi.org/10.2196/12994

[18] Van Dijk T, Spil T, van der Burg S, et al. Present or Play: Some First Evidence on the Effect on Behaviour of Serious Gaming. In 8th European Conference on Games Based Learning: ECGBL 2014, Berlin, Germany, 9-10 October 2014 (pp. 84-92). Curran Associates Inc. 2014. Available from: https://research.utwente.nl/ en/publications/present-or-play-some-first-evidenc e-on-the-effect-on-behaviour-of

[19] Alqahtani N, Innab A, Bahari G. Virtual education during COVID19: exploring factors associated with e-learning satisfaction among Saudi nursing students. Nurse Educator. 2014; 46(2): 18-22. PMid:33234836 https://doi.org/10.1097/NNE.0000000000 000954

[20] Griffiths J. E-learning, during the pandemic and beyond. British Journal of Community Nursing. 2020; 25(6): 265. PMid:32496855 https://doi.org/10.12968/bjcn.2020.25.6.265

[21] Koops MC. Game didactiek. Amsterdam: Didactica. 2017.

[22] Green JL, Suresh V, Bittar P, et al. The utilization of video technology in surgical education: A systematic review. Journal of Surgical Research. 2019; 235: 171-180. PMid:30691792 https: //doi.org/10.1016/j.jss.2018.09.015

[23] Cant RP, Cooper SJ. Simulation in the Internet age: The place of Web-based simulation in nursing education. An integrative review. 
Nurse Education Today. 2013; 34(12): 1435-1442. PMid:25156144 https://doi.org/10.1016/j.nedt.2014.08.001

[24] Yousef AMF, Chatti MA, Schroeder U. The state of video-based learning: A review and future perspectives. International Journal on Advanced in Life Science. 2014; 6(3-4): 122-135.

[25] Ricciardi F, De Paolis LT. A Comprehensive Review of Serious Games in Health Professions. International Journal of Computer Games Technology. 2014. https://doi.org/10.1155/2014/7 87968

[26] Yip J, Wong SH, Yick KL, et al. Improving quality of teaching and learning in classes by using augmented reality video. Computers $\&$ Education. 2019; 128: 88-101. https://doi.org/10.1016/j.co mpedu. 2018.09.014

[27] Habes V, Van Rhijn K, Vredenburg H, et al. Met serious soap spelenderwijs leren. Onderwijs en gezondheidszorg. 2011; 35(3): 22-26. https://doi.org/10.1007/s12477-011-0036-5

[28] Kam CC. The 'making off' van de eerste zorgsoap in Nederland. Coöperatie jongeren werken in de zorg. 2013. Available from: https://docplayer.nl/3117949-The-making-off-v an-de-1e-zorgsoap-in-nederland-malaika.html

[29] Jang K, Kim SH, Oh JY, et al. Effectiveness of self-re-learning using video recordings of advanced life support on nursing students' knowledge, self-efficacy, and skills performance. BMC Nursing. 2021; 20(1): 1-10. PMid:33789625 https://doi.org/10.1186/s129 12-021-00573-8

[30] Wright N, Charnock D. Challenging oppressive practice in mental health: The development and evaluation of a video based resource for student nurses. Nurse Education in Practice. 2018; 33: 42-46. PMid:30236836 https://doi.org/10.1016/j.nepr.2018.08 .016

[31] Musa D, Gonzalez L, Penney H, et al. Interactive Video Simulation for Remote Healthcare Learning. Frontiers in Surgery. 2021; 287 https://www.frontiersin.org/articles/10.3389/fsurg.2021.713119/full

[32] Johnsen HM, Fossum M, Vivekananda-Schmidt P, et al. Developing a serious game for nurse education. Journal Gerontological Nursing 2018; 44(1): 15-19. PMid:29355884 https://doi.org/10.392 8/00989134-20171213-05

[33] Craig P, Petticrew M. Developing and evaluating complex interventions: Reflections on the 2008 MRC guidance. International Journal of Nursing Studies. 2013; 50(5): 585-587. PMid:23159017 https://doi.org/10.1016/j.ijnurstu. 2012.09.009

[34] Wilson LO. Anderson and Krathwohl-Bloom's taxonomy revised. Understanding the New Version of Bloom's Taxonomy. 2016. Available from: http://www0.sun.ac.za/ctlresources/wp - content/uploads/2018/11/Anderson-and-Krathwohl.-2 001.-Extract-from-A-taxonomy-for-learning-teachin g-and-assessing-a-revised-Blooms-Taxonomy.pdf

[35] Caillois R. Man, play and games (M. Barash, Trans.). Champaign, IL: University of Illinois Press; 1961.

[36] Dikken J, Hoogerduijn JG, Kruitwagen C, et al. Content validity and psychometric characteristics of the "Knowledge about Older Patients Quiz" for nurses using item response theory. Journal of the American Geriatrics Society. 2016; 64(11): 2378-2383. PMid:27627575 https://doi.org/10.1111/jgs. 14476

[37] Habes EV, Jepma P, Parlevliet JL, et al. Video-based tools to enhance nurses' geriatric knowledge: A development and pilot study. Nurse Education Today. 2020; 90: 104425. PMid:32311666 https: //doi.org/10.1016/j.nedt.2020.104425

[38] Van Schoot G. Trailer serioussoap [Video file]. 2015. Available from: https://www. youtube. com/watch?v=FLAo8F-mywg

[39] ACTIZ. Serious soap - Behind the scenes [Video file]. 2015. Available from: https://vimeo.com/133988378
[40] Van den Berg F. Serious soaps over de ouderenzorg. Onderwijs en Gezondheidszorg,. 2016; 40(6): 8-9. Available from: https://onderwijsengezondheidszorg.nl/jaargang en/2016/6/serioussoapsoverdeouderenzorg.html

[41] Actie Leer Netwerk. Koploper Serioussoaps. 2016. Available from: https://www. actieleernetwerk.nl/artikel/koplop er/serious-soaps/

[42] McCormack B, Manley K, Titchen A. (Eds.). Practice development in nursing and healthcare. New York, NY: Wiley. 2013.

[43] Munten G, Legius M, Niessen T, et al. Practice development: naar duurzame verandering van zorg-en onderwijspraktijken. Amsterdam: Boom. 2012.

[44] Marlow A, Spratt C, Reilly A. Collaborative action learning: A professional development model for educational innovation in nursing. Nurse Education in Practice. 2008; 8(3): 184-189. PMid:17716945 https://doi.org/10.1016/j.nepr.2007.07.001

[45] Bogers M, Kleijer F. Humor als verpleegkundige interventie 2.0. Berlin: Springer; 2018.

[46] Geri N, Winer A, Zaks B. Challenging the six-minute myth of online video lectures: Can interactivity expand the attention span of learners? Online Journal of Applied Knowledge Management (OJAKM). 2017; 5(1): 101-111. https://doi.org/10.36965/0JAKM. 201 7.5(1) 101-111

[47] Goriup J, Stričević J, Sruk V. Is education for using humour in nursing needed? Slovenian case study on sociological and ergonomic aspects of the impact of humour on nursing professionals. Acta Educationis Generalis. 2017; 7(3): 45-62. https://doi .org/10.151 5/atd-2017-0023

[48] Liu YP, Sun L, Wu XF, et al. Use of humour in medical education: a survey of students and teachers at a medical school in China. BMJ Open. 2017; 7(11): e018853. PMid:29187417 https: //doi.org/10.1136/bmjopen-2017-018853

[49] Ulloth JK. The benefits of humor in nursing education. Journal of Nursing Education. 2002; 41(11): 476-481. https : //doi .org/10 .3928/0148-4834-20021101-06

[50] Koivisto JM, Haavisto E, Niemi H, et al. Elements explaining learning clinical reasoning by playing simulation game. International Journal of Serious Games. 2016; 3(4): 29-40. https ://doi.org/10.170 83/ijsg.v3i4.136

[51] Fontys. Realistische ER-filmpjes trekken landelijk aandacht. 2020. Available from: https://bron.fontys.nl/realistische-e r-filmpjes-trekken-landelijk-aandacht/

[52] Donnelly F, McLiesh P, Bessell SA. Using 360 Video to Enable Affective Learning in Nursing Education. Journal of Nursing Education. 2020; 59(7): 409-412. PMid:32598013 https://doi.org/10.3 928/01484834-20200617-11

[53] Kaczmarczyk J, Davidson R, Bryden D, et al. Learning decision making through serious games. The Clinical Teacher. 2016; 13(4): 277282. PMid:26213136 https://doi .org/10.1111/tct. 12426

[54] Bonk CJ, Graham CR. The handbook of blended learning: Global perspectives, local designs. New York, NY: Wiley; 2012.

[55] Dochy FJRC, Berghmans I, Koenen AK, et al. Bouwstenen voor high impact learning: Het leren van de toekomst in onderwijs en organisaties. Amsterdam: Boom Lemma. 2015.

[56] Laamarti F, Eid M, El Saddik A. An overview of serious games. International Journal of Computer Games Technology. 2014; 14(11): 11. https://doi.org/10.1155/2014/358152

[57] Kaczmarczyk J, Davidson R, Bryden D, et al. Learning decision making through serious games. The Clinical Teacher. 2016; 13(4): 277282. PMid:26213136 https://doi.org/10.1111/tct. 12426

[58] Muller DA. Designing effective multimedia for physics education. Sydney: University of Sydney. 2008. 